\begin{tabular}{|c|c|c|c|c|c|}
\hline SRA (India) & $=3.117$ & SIS (USA) & $=0.912$ & ICV (Poland) & $=6.630$ \\
\hline SI (Dut & & РИНЦ (Russia & $=0.156$ & PIF (India) & $=1.940$ \\
\hline IF (Australia) & $=0.564$ & ESJI (KZ) & $=8.716$ & IBI (India) & $=4.260$ \\
\hline JIF & $=1.500$ & SJIF (Morocco & $=5.667$ & OAJI (USA) & $=0.350$ \\
\hline
\end{tabular}

\section{International Scientific Journal Theoretical \& Applied Science}

p-ISSN: 2308-4944 (print) e-ISSN: 2409-0085 (online)

Year: 2019 Issue: 02 Volume: 70

Published: 06.02.2019 http://T-Science.org
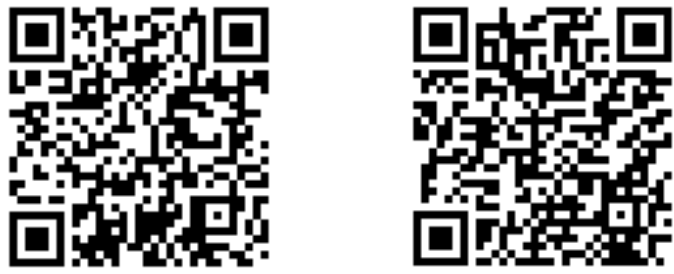

M. Bahti Ochilova

Doctor of Philosophy, Doctorate,

Professor JSPI, Head of Social Sciences Department,

A. Dushaev

Teacher of National Ideology and Enlightenment Bases, Education of Rights Department Guliston State University, bobo7805@mail.ru

\title{
THE CATEGORY OF RELEVANCE: PHILOSOPHICAL ANALYSIS
}

Abstract: Central connection (relevance) among all alive (animate) and lifeless (inanimate) organisms in this universe is expressed through concept of association solidarity.

Key words: Relevance, mutual relations, general connection, partnership, religion, science, Physics, Quran, Philosophy, association, Bells theorem, Quantum mechanics, relative mechanics.

Language: English

Citation: Ochilova, M. B., \& Dushaev, A. (2019). The category of relevance: philosophical analysis. ISJ Theoretical \& Applied Science, 02 (70), 11-14.

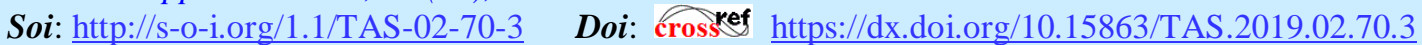

\section{Introduction}

Relevance is the most overall philosophical term which encompasses the notions of selfformation of matter in whole universe (synergy), coaffected and causally related (determinism), coattracted and co-repulsed (gravitational and gyroscopic acts) events.

Relevance is explained by its micro, macro, and mega-universe forms. It is attributed by different material objects, events; and they, in turn, possess various peculiarities and structures at the same time. Previously, there existed and prevailed the idea which stated that all objects are the inseparable forms of matter, and that they are consisted of atoms. To date, the scientific hypotheses that atoms are complex structures themselves have been proved.

Atoms consist of complex root neutron, positron, i.e. nucleus and electron layers. The nucleus of hydrogen atom consists of one proton. The nucleus of more complex atoms consists of several protons and neutrons. Protons and neutrons consist of quarks and interconnecting gluons. Protons and neutrons are nucleons (from Latin nucleus, root); and except nucleons and hyperons (from Greek above, on the upper) they are composed of baryons and hadrons (from Greek adros-heavy). As being massive elements, they are in strongly inter-affected fields and belong to hadrons class. These micro-universal elements are interrelated and they have been created in pairs. "The ALLAH created everything in pairs from the known and unknown (Allah is flawless and immaculate)" [1, Surah 36]. The fact stated in this Holy Ayat that everything possesses its opposite pair have been proved scientifically. Hence, all existing opposite pairs in objective reality (electron-positron, proton-antiproton, negative-positive, man-woman, etc.) are interrelated and mutually complementary. Organic and non-organic substances differ from each other by their molecular structure, system. Animate organisms include complex organic substances.

The content of animate organisms is composed of cell and systems of cells. One may regard the earth's biosphere as a single animate, alive system. It comprises microorganisms, plants, animals, and human beings. The complex (system) of interrelatedness among them secures and supports the life in biosphere. "It (The Everlasting) created plants, and then transformed it to oil..." (Mukhammad) Your Lord ordered the bee: "Nestle mountains, trees and houses. Then, eat all kinds of fruits, and fly securely and safely the path which the Creator made safe and easy for you!". "It produces crimson liquid-honey, which is remedial for people". "The inanimate and lifeless earth (ground) is a token for them; we gave life to it (by means of rain), we harvested, seeded, they'll consume it", "Can't they 


\begin{tabular}{|c|c|c|c|c|c|c|}
\hline \multirow{4}{*}{ Impact Factor: } & ISRA (India) & $=3.117$ & SIS (USA) & $=0.912$ & ICV (Poland) & $=6.630$ \\
\hline & ISI (Dubai, UAE & $=0.829$ & РИНЦ (Russia) & $=0.156$ & PIF (India) & $=1.940$ \\
\hline & GIF (Australia) & $=0.564$ & ESJI (KZ) & $=8.716$ & IBI (India) & $=4.260$ \\
\hline & JIF & $=1.500$ & SJIF (Morocco) & $=5.667$ & OAJI (USA) & $=0.350$ \\
\hline
\end{tabular}

see how camel has been created" $[4,87,16,36,88$ surahs]. One may suggest from these ayahs that the earth (universe) that comprises various microuniversal elements, natural resources, fauna and flora and human beings are inseparably interconnected and interrelated.

12, 13, 14 ayahs in "Anom" surah of Holy Quran: "Tell (ask): "Who is the owner of heaven and earth? Tell: 'Allah's"'. The following can be inferred from the above ayahs: the Allah created the objective reality and made relevant to itself. Whole universe must obey and worship the only Creator. Indeed, when creating objective reality the Allah implied their interrelated with each other and the only relevance only to itself. "Within two days He created seven skies and obliged relevant tasks, functions, obligations, assignments for each one". The universe immaculately and flawlessly created by God is ultimately mutually complementary, interrelated and interdependent (gravitational and gyroscopic). We can also observe it in the following ayahs: "Oath to shimmering stars, (clandestine) planets, dusk and dawn..." [1, 81 surahs]. These ayahs from contemporary physical scientific viewpoint can be interpreted as follows: "It has a reversive secretive power and flaws back to its orbit".

\section{Materials and Methods}

The relevance of the whole objective reality can't be elucidated more succinctly and concisely. It should be noted that Bells theorem grounded on the Quantum mechanics in contemporary physics coincide with the facts in Holy Qoran! If objective reality (space) does really exist, and if equation of Quantum mechanics structurally coincides with objective reality, in that case, there is a nonlocalized connection among interconnected, interrelated elements ever existed (It should be remembered that classical, primitive, base form of nonlocalized connection is a "miraculous" connection). In this point, "It's well known that we created man, human being out of pitch black bog. And, after giving him a human being structure, created him out of dried clay" or "Indeed, I am the one who creates out of clay" [1, 15-38 surahs] (We contemplate that miraculous connection is a preliminary impetus of God). Moreover, up-to-date science has identified all components of ground, earth, clay in human body structure. Consequently, these ayahs have their scientific adductions. Clay, (bog, ground, earth) is the only substance which possesses self-composing, self-constituting (synergy), and recovering, restoring reaction (determinism) peculiarities in nature. In all space models before Quantum mechanics, in Einstein's Theory of relativity as well, each interaction requires any connection accordingly. In Newton physics it was mechanic and deterministic connections; in thermodynamics it was mechanic and statistic connections; in electromagnetism it was field intersections and interaction connections; and in theory of relativity it was space refraction. At any case, interaction always suggests any connection (It can be exemplified by the billiard game). Bell's theorem stipulated scientists to choose between the two: whether to accept fundamental indeterminism of quantum mechanics, or admit the existence of telepathy (like Einstein's nonlocality phenomenon) in nature.

According to Bell's theorem, experiments have shown the existence of nonlocal latent changers proposed by Einstein.

As it's very crucial for us, we would like to memorize Bell's theorem once again. According to the theorem, there is no isomerous system in objective reality. Every particle instantly connects with other particles in it. No energy is consumed in instantaneous connections.

Dr. J. Saffati considers that Bell's connections need to occur by mens of information. Doctor in physical sciences, E.G. Woker believes that there should be some indefinite element "consciousness". It should be reminded that nowadays consciousness has rather different interpretations than of classical philosophy which gives priority to material aspect of consciousness.

When speaking about inanimate, lifeless nature, first of all, Space relevance, connection is always meant. The earth and its satellite, the moon, completely rotate the sun in one year. "...(Allah) Then facing smoky sky, to the sky and earth said: (According to my order) willingly or compulsory come!". They said: "We've come willingly, (bend to Your will!)" [1, 41 surahs]. The following can be inferred from the above: being located far from the sun, the earth can ultimately supply living conditions for human beings, fauna and flora as well.

The sun, as a crucial life source of biosphere, provides thermal and electromagnetic balance in the universe. In relation to its orbit, the earth is diagonally located, and it makes it possible for seasons to change which means that all life processes are interconnected with the processes among the Earth, the sun, and the moon. Besides the earth, other planets, their satellites, asteroids, meteors and comets travel around the sun. They altogether make up the Solar system.

These three worlds are inseparably interconnected, and they can interchange, i.e. microworld may transform into macro- and mega-worlds and vice versa.

Development of matter implies changes in its constituent structure. According to the levels of constituent structure, we divide matter into nonorganic matter, organic matter and social matter. They differ from each other by their relevance verities. In nonorganic matter or in inanimate, lifeless nature physical or chemical relevance, connections prevail. In animate nature, namely in organic world, 


\begin{tabular}{|c|c|c|c|c|c|c|}
\hline \multirow{4}{*}{ Impact Factor: } & ISRA (India) & $=3.117$ & SIS (USA) & $=0.912$ & ICV (Poland) & $=6.630$ \\
\hline & ISI (Dubai, UAE & $=0.829$ & РИНЦ (Russia & $=0.156$ & PIF (India) & $=1.940$ \\
\hline & GIF (Australia) & $=0.564$ & ESJI (KZ) & $=8.716$ & IBI (India) & $=4.260$ \\
\hline & JIF & $=1.500$ & SJIF (Morocco & $=5.667$ & OAJI (USA) & $=0.350$ \\
\hline
\end{tabular}

biological relevance is more active and complex. In social stratum, except the above enumerated relevance and connections, there exist social relevance and connections. Each man as an element of matter's structure, reflects all kinds of social relevance and connections, and consciously or subconsciously partakes in all social relevance and connections [4, 124-125].

Nowadays, the world's geopolitical, economic and social, information-communication dimensions have been radically changing and transforming. So, at this stage, we must fight, struggle against idea with an idea, against illiteracy with an education and enlightenment.

It's clear that in order to prevent any illness, ailment, and disease one should create immunity. We must and should inculcate love for motherland, parents, people into our children's souls in order to upbring them spiritually and morally good. We have to form and fortify ideological immunity against evil and injustice [5, 119].

The first President of Uzbekistan Islam Karimov's standpoints on this issue have great impact on our youth.

The notion of the feeling of relevance pertains to human being nature and it has mutual dual relations, like: human to human, human to society, and human to nature. Still, they do not function alone, on the contrary they operate in unity complementing and inter, mutually relating closely with each other. Man and society are inalienable and integral, and, at the same time, independent parts of the nature. Society always interacts with nature. Man always abides in nature. Man can never live outside or without getting into relation with nature. Nature and society, nature and man, the history of nature and the history of society are in dialectical unity, in interaction, and in counter-interaction. They can never be separated. Each and any man, the world of society and human beings theoretically and practically live in mutual connection and relevance.

The moral bases of the feeling of relevance have ancient roots. Ancient tribes and clans abode by certain rules and moral codes. Namely, they used to live on the grounds of the feeling of relevance in relation to their relatives, clans, and tribes. They protected their values and families. The prevalent moral-religious teachings of totemism had a great affect on the formation of moral-spiritual relevance. The totemism teaching and theory cultivated not only tribal relations, but also natural relations as well.

Moral relations towards man, society, and nature were taught in Avesto teachings as well. Seven-year-old children took an oath to be loyal to zardushtra religion, and not to sin. The believers and followers of the religion (Zardushtra teaching) have a strong faith in the power of education and knowledge. According to them, "The only good is knowledge, and the only evil is ignorance". The elders and parents cultivated and inculcated moral, labor-loving, integrity, graciousness, and generosity characteristics in youth $[6,22]$.

There are a number of Hadithats about moral and spiritual traits of human beings, for instance: "Nabiy sallolohu alayhi va sallam said: "Each muslim should give alms and donate". People asked: "What if we cannot find anything to give alms? Rasulullokh said: "Labor with hands, get profit and give alms! People said: "What if one is unable to work?" Rasulullokh said: "Let them assist to the crippled and invalid!". People said: "What if one can't do this either?". The Rasullullokh said: "Let them call others to do good!”. People again asked: “ What if one can't do this as well?". The Rasulullokh answered: "Let him refrain himself from doing evil to others! This shall be counted as a donation and alms for him!". The Rasulullokh asked: "Hey, Oyisha! When did you notice me being immoral?! At the Doomsday the baddest mortal in the eyes of Allakh is the one who is squeamish about other people's imperfections" [7, 89-90-92]. (The gist, crux, moral, and logic of this Hadithat is that one should not be fastidious about bad, immoral people, but should communicate with them; do and be good to them as well!).

\section{Conclusion}

The following opinions support and reflect the above stated facts of being amiable, amicable, and gracious towards other people. If a man have not been properly educated and cultivated; if a man has not gained a sufficient experience in life, he will diminish, underestimate, belittle things and values in society; he will be fastidious about relations. If anyone hankers after and is for the education, knowledge, science, health, morals, courteousness, integrity, one should implant these traits and features from early childhood. And, one should keep his word, abide by his promise, and moral conduct, refrain, abstain from doing, committing sin, evil; decline from disloyalty, adultery, and hypocrisy [8, 182].

Man is not borne moral, ethical or immoral, unethical. Human beings are not borne with ready, prepared characteristics, traits, skills, knacks, or flaws, imperfections. Moral and ethical standards, overall personal peculiarities will be inculcated and cultivated during the lifespan of man, within the life and ages he outlives during course of life [9, 115119].

Man should cleanse, purify his distinguishing quality from any malice, material gain, and spite. Religion recognizes its owner and follower. If you hang with, enjoy the company of people who have lost their distinguishing quality, you'll not distinguish and recognize your religion and path, call in life. You have fed, bred and nurtured your body; nonetheless, it has no distinguishing, differentiating, 


\begin{tabular}{|c|c|c|c|c|c|c|}
\hline \multirow{4}{*}{ Impact Factor: } & ISRA (India) & $=3.117$ & SIS (USA) & $=0.912$ & ICV (Poland) & $=6.630$ \\
\hline & ISI (Dubai, UAE & $=0.829$ & РИНЦ (Russia & $=0.156$ & PIF (India) & $=1.940$ \\
\hline & GIF (Australia) & $=0.564$ & ESJI (KZ) & $=8.716$ & IBI (India) & $=4.260$ \\
\hline & JIF & $=1.500$ & SJIF (Morocco & $=5.667$ & OAJI (USA) & $=0.350$ \\
\hline
\end{tabular}

discriminating, detecting quality at all. Distinguishing is a quality. Can't you see that jinn has arms and legs, but it has no distinguishing quality. Distinguishing is a tender, sensual, elegant, graceful meaning in you; and you keep on attempting to feed your sordid body depraved of these traits and quality day and night. The body is only alive with a meaning. It's like seeing, observing, contemplating the sun with a lamp. In fact, one can see the sun without a lamp. One need not be disappointed with God! Hope, faith, and confidence is the threshold of the path. Even if you are not stepping on the path, always target the beginning of the path. "Never say that you've done bad things; but keep on doing good!". In that case, no insincerity will leave [10, 21 22]. Thus, Mavlono Rumiy has the insight into the depth of human soul and nature. He narrates and relates human being's pearl of iman, greatness, magnificence and flaws, imperfections resulted from his carnal desires. He analyses the ways and means to get rid of them, to purify soul, etc. Hence, he elucidated the ways man can achieve the heights of spirituality with vivid examples.
Relying on the above enumerated and exemplified opinions and convictions, it's indispensable to state that the notion of relevance is applicable towards all matters, events, and phenomena in objective reality. But, the feeling of relevance (in this context moral-humane relation) is a notion and feeling that relates and pertinent to only and only human being.

The first President of Uzbekistan Islam Karimov stated: "When conversing about protecting and safeguarding younger generation from various spiritual and ideological threats and dangers, we need to openly address ourselves not only to positive aspects of our nation and society, but also to negative residues and customs that may stagnate and derail the development processes. Above all, we have to contemplate on total eradicating and eliminating egoism, egocentrism, carelessness, negligence, corruption, mercenariness, arrogance, tribalism, and tribal segregation. I would like this very crucial and central issue to be under the profound consideration and meticulous, rapt attention of our society, especially of our intellectuals, art members, scientists and scholars" [5, 119-121].

\section{References:}

1. (1992). Qurani Karim (translations and interpretations by Alouddin Mansur). (p.36). T.: Chulpon.

2. Nurboqiy, H. (2002). The scientific miracles of Qurani Karim. (p.16). T.: Adolat.

3. (2010). The philosophical issues of synergy. (pp.57-58). T.: UzMU.

4. (1999). Philosophy. Under the edition of Erkin Yusupov. (pp.124-125). T.: Sharq.

5. Karimov, I. A. (2008). Great education and enlightenment is an invincible power. (p.119). T.: Ma'naviyat.
6. Yuldoshev, J., \& Hasanov, S. (1992). The moral educational issues in Avesto. (p.22). T.: Uqituvchi.

7. Imom, al-Bukhoriy (1992). Al-jomiy as-sahih. (pp.89-90-92). T.: Encyclopedic editions.

8. Forobiy, Abu Nasr. (1993). The city of intelligence. (p.182). T.: Public legacy editions.

9. Ibn Sina (2003). The story of Tayr. (pp.115119). T.: Fan.

10. Jaloliddin, Rumiy (2013). Insight. (pp.21-22). T.: Generation of new century. 